\title{
A Study on Problems and Prospects of Online Stock Trading in Solan Town of Himachal Pradesh
}

\author{
Arshia Bansal", Neha Kashyap, Piyush Mehta and Krishan Kumar Raina
}

Dept. Of Business Management, Dr. Y. S. Parmar University of Horticulture and Forestry, Nauni, Solan, H. P. (173 230), India

\section{Corresponding Author}

Arshia Bansal

e-mail: bansal.arshia20@gmail.com

\author{
Article History \\ Article ID: IJEP0273 \\ Received in $21^{\text {st }}$ September, 2018 \\ Received in revised form $10^{\text {th }}$ October, 2018 \\ Accepted in final form $22^{\text {nd }}$ October, 2018
}

\begin{abstract}
The study was conducted in Solan town of Himachal Pradesh, it explore various practices which can help to educate an investor so that problem of trading can be overcome and its scope can be highlighted. For this study, sample size was 120 which was taken from Solan town of Himachal Pradesh. The study was undertaken with the objective of understanding the advantages, disadvantages and future prospects of online trading. The study has observed that maximum respondents were of the age group 30-40 years and also observed that changes in the income reflect that more people start investing as there income increases. Government officials were largely inclined for investment options involving high risk investment. Eagerness was seen among the investors to at least get back the amount they had invested. The investors' seen to be satisfied by the types of choices available to them. New trading mechanism can be formed to allow the trading of stocks in the world's global companies. Non adopters can be encouraged to trade online by offering incentives. As hacking is very common in case of online trading so there is a need to review the security system.
\end{abstract}

Keywords: Online stock trading, investors, brokers, risk, income

\section{Introduction}

Stock is a share in the ownership of a company. Holding a company's stock means that you are one of the many owners (shareholders) of a company and you have a claim to everything the company owns (Maran and Sarkar, 2013). Online trading was started in India in the year 1995, where a new system is formed which allow the investors to trade through an internet site where banks and Demat accounts are electronically integrated. The internet can provide wide exposure for those hoping to market themselves or their companies, but it can also provide anonymity for those who wish to exchange information without revealing all of their personal data (Srivastava, 2002). Automation of the broking processes results in reduced manpower requirement, flexibility of time, less infrastructure cost, etc. offering significant cost savings to the broker. (Raman and Jain, 2013).After going online, the investors' realized that trading can be done more actively and it made the market lagging more than 3\% annually (Brad and Terrance, 2002). Service quality factors leading to dissatisfaction in online trading were responsiveness $31 \%$, service reliability $12 \%$, ease of use $11.3 \%$, competence $0.03 \%$, access $9.6 \%$, system reliability $7.8 \%$, timeliness $6.6 \%$, and security $3.8 \%$. These were the most often services that any investor would think off (Yang and Fang, 2004). The effect of online and offline trading on effective market performance on the NASDAQ stock exchange was often a hybrid of dealer and auction markets (Haroun et al., 2006). Indian investors' are more conservative, they don't change easily and Indian offline traders will choose brokers for trading. It was found that online traders were more comfortable by trading methods because of transparency and complete control over the terminals (Nidhi and Ravinder, 2007). Investors' age are the main factors which decide the risk taking capacity of investors' and that the modern investor is mature and rational when taking investment decision (Kabra et al., 2010). Indian investors even if they are of high income, well educated, salaried, and independent are conservative investors' who prefer to play safe in the market (Syed, 2010). Online trading has given customers benefits like real time access to account information, stock quotes, elaborated market research and interactive trading (Kafeel, 2012). Indian investors were more conservative, middle aged, educated and have sufficient income base (Balaji, 2014). Online trading is highly beneficial and cheap in terms of money and time. Certainalterations are however required to make it more fruitful (Arvinder et al., 2015). Online trading is on a risingtrack and is gaining its momentum very fast (Yannis, 2016). The online trading is the world of internet being accessed by investors with their liberty in terms of types of investments, stocks etc. (Laveena et al., 2015). Who 
perceived the online trading as easy to use, have no difficulty in accessing it from home or work have perception of ease of use is a significant factor influencing attitude towards online trading adoption (Krishna and Merugu, 2015).

\section{Materials and Methods}

The descriptive research design was adopted for the concerned research study. The research was conducted in Solan town of Himachal Pradesh in 2017. The respondents were selected by convenience sampling depending on availability of respondents. The sample size for the study was conducted on 120 respondents i.e. businessman, private, public, government, others. Two types of data have been collected for the study.Primary data was collected through closed ended structured interview schedule. The questionnaire was divided into two parts. Part ' $A$ ' was designed to seek information on the demographic variables such as name, gender, age, income etc. Part ' $B$ ' consisted of general views and statements based on likertscale to evaluate investors' behaviour towards benefits, problems and prospects of online trading. Secondary data was taken from journals, magazines, research articles, newspaper, and books. Simple mathematical and statistical tools including Arithmetic Mean, Standard Deviation, Percentage and Total Weightage Score method were used for satisfying the objectives with a view of keeping the analysis simple and easy to understand. The concerned study was initiated with the key objective, to study the benefits of online stock trading and also the problems faced by investors in online stock trading.

\section{Results and Discussion}

\subsection{Age Status of respondents}

In reference to understand the age status of respondents, it was perceived that respondents having the age group of 30-40 years were largely taken as a sample size. At this age group, investors were more inclined for stock option investments and were also observed to be tech savvy and were more likely to trade online (Table 1).

\begin{tabular}{|c|c|c|}
\hline \multirow[t]{2}{*}{ Age (years) } & \multicolumn{2}{|c|}{ Frequency } \\
\hline & No. of respondents & $\%$ age \\
\hline $20-30$ & 30 & 25.00 \\
\hline $30-40$ & 50 & 41.60 \\
\hline More than 40 & 40 & 33.40 \\
\hline Total & 120 & 100 \\
\hline
\end{tabular}

Source: Primary survey, 2017

\subsection{Age status of various respondents (stock investors)}

The age status of respondents (stock investors) in accordance to the occupational status of the respective respondents. It was observed that in the age group ranging $20-30$ years largely respondents were holding the occupational status of private job or entity, while in the age group ranging 30-40 years largely respondents were holding the occupational status of Professional job (Doctor, Professor, Advocates, teachers etc.) and in theage group ranging more than 40 years largely respondents were holding the occupational status of Government job (Table 2).

\begin{tabular}{|c|c|c|c|c|c|}
\hline \multicolumn{6}{|c|}{ No of respondents } \\
\hline $\begin{array}{l}\text { Age } \\
\text { (years) }\end{array}$ & $\begin{array}{c}\text { Busi- } \\
\text { nessman }\end{array}$ & $\begin{array}{l}\text { Profes- } \\
\text { sional }\end{array}$ & $\begin{array}{c}\text { Govern- } \\
\text { ment }\end{array}$ & Private & Others \\
\hline $20-30$ & $4(16.70)$ & $\begin{array}{c}5 \\
(20.80)\end{array}$ & $1(4.20)$ & $\begin{array}{c}11 \\
(45.90)\end{array}$ & $2(8.30)$ \\
\hline $30-40$ & $\begin{array}{c}14 \\
(58.30)\end{array}$ & $\begin{array}{c}16 \\
(66.70)\end{array}$ & $\begin{array}{c}5 \\
(20.80)\end{array}$ & $\begin{array}{c}2 \\
(8.30)\end{array}$ & $\begin{array}{c}7 \\
(29.20)\end{array}$ \\
\hline $\begin{array}{l}\text { More } \\
\text { than } 40\end{array}$ & $6(25.00)$ & $\begin{array}{c}3 \\
(12.50)\end{array}$ & $\begin{array}{c}18 \\
(75.00)\end{array}$ & $\begin{array}{c}11 \\
(45.80)\end{array}$ & $\begin{array}{c}15 \\
(62.50)\end{array}$ \\
\hline Total & $24(100)$ & $\begin{array}{c}24 \\
(100)\end{array}$ & $\begin{array}{c}24 \\
(100)\end{array}$ & $\begin{array}{c}24 \\
(100)\end{array}$ & $\begin{array}{c}24 \\
(100)\end{array}$ \\
\hline
\end{tabular}

Source: Primary survey, 2017; Percentage in brackets

\subsection{Marital status of the respondents (stock investors)}

From the collected data it is clear that more people start investing after they get married. A married person has to make more profitable investments to secure his or her future (e.g. child education, emergency in family, retirement etc.). From 120 respondents, 92 agreed that they start investing more after they get married and only 28 unmarried respondents were found who make more investments than expenses (Table 3).

Table 3: Marital Status of respondents

\begin{tabular}{lcc}
\hline Marital status & \multicolumn{2}{c}{ Frequency } \\
\cline { 2 - 3 } Single & No. of respondents & $\%$ age \\
Married & 28 & 23.00 \\
Total & 92 & 77.00 \\
\hline
\end{tabular}

Source: Primary survey, 2017

\subsection{Marital status of the respondents (stock investors)}

The marital status of respondents in accordance to the occupational status of respective respondents. It is depicted from the responses that in every category i.e. businessman, professional, government, private and others most of the people start investing after marriage. From the analysis it is observed that professionals have hike in their results of investments $91.7 \%$ over other categories, followed by Government category $70.8 \%$ and in case of others only $66.7 \%$ investments were made after marriage. A small percentage 
of investors were found to be investing before marriage in each case (Table 4).

\begin{tabular}{lccccc}
\hline \multicolumn{7}{c}{ Table 4: Marital status of the respondents (stock investors) } \\
\hline \multicolumn{7}{c}{ No of respondents } \\
Marital & $\begin{array}{c}\text { Busi- } \\
\text { nessman }\end{array}$ & $\begin{array}{c}\text { Profes- } \\
\text { sional }\end{array}$ & $\begin{array}{c}\text { Govern- } \\
\text { ment }\end{array}$ & Private & Others \\
\hline Single & 6 & 2 & 7 & 5 & 8 \\
& $(25.00)$ & $(8.30)$ & $(29.20)$ & $(20.80)$ & $(33.30)$ \\
Mar- & 18 & 22 & 17 & 19 & 16 \\
ried & $(75.00)$ & $(91.70)$ & $(70.80)$ & $(79.20)$ & $(66.70)$ \\
Total & 24 & 24 & $24(100)$ & 24 & 24 \\
& $(100)$ & $(100)$ & & $(100)$ & $(100)$ \\
\hline
\end{tabular}

Source: Primary survey, 2017; Percentage in brackets

\subsection{Income status of the respondents}

The income changes investment size also changes. There is a large shift in number of respondents as the income changes. More people start investing as there income varies between 2-3 lakhs. At this stage they have sufficient amount of money in hand and can have a diversified portfolio. They may not made changes in that portfolio because according to collected data people invest less as there income becomes more than 3 lakhs (Table 5).

\begin{tabular}{lcc}
\hline \multicolumn{3}{l}{ Table 5: Income status of the respondents } \\
\hline Income status & \multicolumn{2}{c}{ Frequency } \\
\cline { 2 - 3 } & No. of respondents & $\%$ age \\
Less than 2 lakh & 28 & 23.30 \\
2-3 lakh & 70 & 58.30 \\
More than 3 & 22 & 18.40 \\
lakh & & \\
Total & 120 & 100 \\
\hline
\end{tabular}

Source: Primary survey, 2017

\subsection{Income status of the respondents (stock investors)}

The income status in accordance to the occupational status of respective respondents. It was observed that when the income size becomes 2-3 lakhs more people start investing. More businessmen $58.3 \%$ started investing when their income increased from less than 2 lakhs to 2-3 lakhs. Similarly $79.1 \%$ professionals start investing (Table 6).

3.7. Status of expected changes in annual income in coming years

It was observed that most of respondents think that their income will change by more than $10 \%$ in coming years. The income of the individual is one of the factors, which play a vital role in influencing the investment decisions of an investor. As 36.6 per cent respondents agreed that income will change by more than $10 \%$ in coming years, while only $20 \%$ respondents think that there income will remain same (Table 7).

\begin{tabular}{lccccc}
\hline \multicolumn{6}{c}{ Table 6: Income status of respondents (stock investors) } \\
\hline \multicolumn{5}{c}{ No of respondents } \\
\hline $\begin{array}{l}\text { Income } \\
\text { status }\end{array}$ & $\begin{array}{c}\text { Busi- } \\
\text { nessman }\end{array}$ & $\begin{array}{c}\text { Profes- } \\
\text { sional }\end{array}$ & $\begin{array}{c}\text { Govern- } \\
\text { ment }\end{array}$ & Private & Others \\
\hline Less han & $4(16.70)$ & 3 & $2(8.40)$ & 10 & 9 \\
2 lakh & & $(12.50)$ & & $(41.70)$ & $(37.20)$ \\
2-3 lakh & 14 & 19 & 15 & 12 & 10 \\
& $(58.30)$ & $(79.10)$ & $(62.50)$ & $(50.00)$ & $(41.70)$ \\
More & $6(25.00)$ & $2(8.40)$ & 7 & 2 & 5 \\
than 3 & & & $(29.10)$ & $(8.30)$ & $(4.10)$ \\
lakh & & & & & \\
Total & $24(100)$ & 24 & $24(100)$ & 24 & 24 \\
& & $(100)$ & & $(100)$ & $(100)$ \\
\hline
\end{tabular}

Source: Primary survey, 2017; Percentage in brackets

Table 7: Status of expected changes in annual income in coming years

\begin{tabular}{lcc}
\hline Expected changes in & \multicolumn{2}{c}{ Frequency } \\
\cline { 2 - 3 } annual income & No. of respondents & $\%$ age \\
Increase by 5\% & 20 & 16.70 \\
Increase by 10\% & 32 & 26.70 \\
More than 10\% & 44 & 36.60 \\
Will remain same & 24 & 20.00 \\
Total & 120 & 100 \\
\hline
\end{tabular}

Source: Primary survey, 2017

\subsection{Status of expected changes in annual income in coming years}

It was observed that $41.6 \%$ businessman and $83.3 \%$ government officials are expecting more than $10 \%$ increase in their annual income in the coming years. A bent $45.9 \%$ private official and $54.2 \%$ respondents of other category were also expecting increase by more than $10 \%$ (Table 8).

\subsection{Expected status of appreciation from investments}

Respondents are not expecting much of the appreciation from the investments that they had made. The results are showing a clear picture that $62.5 \%$ of the investors think that they could have only $5 \%$ appreciation from the investments they had made. Reason for the same can be variations in the money markets at large scale and the various steps which are taken by the government for various sectors which would lead to the upliftment of one sector and may affect another sector. Only $20.8 \%$ respondents think that they could have there value of money to be increased by more than $15 \%$ (Table 9).

\subsection{Expected appreciation status from investment}

The status of expected appreciation collected demographically. The figure clearly shows that private sector is showing that expect $5 \%$ increase in the investments they had made 
Table 8: Status of expected changes in annual income in coming years

\begin{tabular}{lccccc}
\hline \multicolumn{5}{c}{ No of respondents } \\
\hline $\begin{array}{l}\text { Expected } \\
\text { changes } \\
\text { in annual } \\
\text { income }\end{array}$ & $\begin{array}{c}\text { Busi- } \\
\text { nessman }\end{array}$ & $\begin{array}{c}\text { Profes- } \\
\text { sional }\end{array}$ & $\begin{array}{c}\text { Govern- } \\
\text { ment }\end{array}$ & Private & Others \\
\hline Increase & 1 & 3 & 1 & 5 & 2 \\
by 5\% & $(4.20)$ & $(12.50)$ & $(4.20)$ & $(20.80)$ & $(8.30)$ \\
Increase & 12 & 4 & 2 & 6 & 5 \\
by 10\% & $(50.00)$ & $(16.70)$ & $(8.30)$ & $(25.00)$ & $(20.80)$ \\
More & 10 & 2 & 20 & 11 & 13 \\
than & $(41.60)$ & $(8.30)$ & $(83.30)$ & $(45.90)$ & $(54.20)$ \\
$10 \%$ & & & & & \\
Will & 1 & 15 & 1 & 2 & 4 \\
remain & $(4.20)$ & $(62.50)$ & $(4.20)$ & $(8.30)$ & $(16.70)$ \\
same & & & & & \\
Total & 24 & 24 & 24 & 24 & 24 \\
& $(100)$ & $(100)$ & $(100)$ & $(100)$ & $(100)$ \\
\hline
\end{tabular}

Source: Primary survey, 2017; Percentage in brackets

\begin{tabular}{lcc}
\hline \multicolumn{2}{l}{ Table 9: Expected status of appreciation from investments } \\
\hline \multirow{2}{*}{$\begin{array}{l}\text { Expected appreciation from } \\
\text { investments by respondents }\end{array}$} & \multicolumn{2}{c}{ Frequency } \\
\cline { 2 - 3 } & $\begin{array}{c}\text { No. of re- } \\
\text { spondents }\end{array}$ & \% age \\
Up to 5\% & 75 & 62.50 \\
$10-15 \%$ & 20 & 16.70 \\
More than 15\% & 25 & 20.80 \\
Total & 120 & 100 \\
\hline
\end{tabular}

Source: Primary survey, 2017

followed by professional as $80 \%$. Investors believe that they would get at least $5 \%$ appreciation from the investment they had made. But same results can be seen for the appreciation more than $15 \%$. Each sector like businessman has shown only $8.3 \%$ results, professional has also shown same results as the businessman. While both the private and others has shown the lowest results i.e. $4.2 \%$, only a small hike of results can be seen in government sector i.e. 16.7\% (Table 10).

\subsection{Investors risk taking ability (respondents)}

More investors are interested to take low risk as no one wants to suffer from losses. High percentage is observed in case of low risk 49.1 per cent. For moderate and high risk only 25.0 per cent and 25.9 per cent is observed. High risk will lead to high profit. Since at earlier stages due to lack of awareness or any other reasons investors don't make much investment (Table 11).

\subsection{Investors risk taking ability of various respondents}

\begin{tabular}{lccccc}
\hline \multicolumn{6}{l}{ Table 10: Expected appreciation status from investment } \\
\hline \multicolumn{5}{c}{ No of respondents } \\
\hline $\begin{array}{l}\text { Expected } \\
\text { apprecia- }\end{array}$ & $\begin{array}{c}\text { Busi- } \\
\text { nessman }\end{array}$ & $\begin{array}{c}\text { Profes- } \\
\text { tion from }\end{array}$ & $\begin{array}{c}\text { Govern- } \\
\text { ment }\end{array}$ & Private & Others \\
invest- \\
ment
\end{tabular}

Source: Primary survey, 2017; Percentage in brackets

Table 11: Investors risk taking ability (respondents)

\begin{tabular}{lcc}
\hline Investors risk taking & \multicolumn{2}{c}{ Frequency } \\
\cline { 2 - 3 } ability & No. of respondents & $\%$ age \\
Low & 59 & 49.10 \\
Moderate & 30 & 25.00 \\
High & 31 & 25.90 \\
Total & 120 & 100 \\
\hline
\end{tabular}

Source: Primary survey, 2017

The high risk taking capability of respondents belonging to government class $75 \%$ and less risk taking capability of respondents falling under private sector $79.2 \%$. The risk taking ability for professionals is $62.5 \%$ and for businessman it is 41.7 per cent. From the 24 respondents in businessman group $33.3 \%$ were found to take moderate risk, for professional the moderate risk percentage was only $20.8 \%$. For government group respondents $16.7 \%$ investors were willing to take moderate risk, and in others group $41.7 \%$ investors were interested in taking moderate risk. $41.7 \%$ businessman was found to take low risk, followed by $8.3 \%$ of government group respondents who were willing to take low risk (Table 12).

\subsection{Average investment status of respondents}

It was observed that only $22.3 \%$ investors invest for 6 months - 1 year, $40 \%$ i.e. maximum investments are made for the time period of 1year -2 year and $35 \%$ investors were found who make investments for more than 2 years. As investor has to earn money than they have to put their money in circulation and check the progress of that particular stock in which they have invested. If they found that particular stock is not showing much progress then they can sell shares of that company before they suffer losses at the price wherever there is hike in price (Table 13). 


\begin{tabular}{lccccc}
\hline \multicolumn{6}{l}{ Table 12: Investors risk taking ability of various respondents } \\
\hline \multicolumn{5}{c}{ No. of respondents } \\
\hline $\begin{array}{l}\text { Investors } \\
\text { risk tak- } \\
\text { ing ability }\end{array}$ & $\begin{array}{c}\text { Busi- } \\
\text { nessman }\end{array}$ & $\begin{array}{c}\text { Profes- } \\
\text { sional }\end{array}$ & $\begin{array}{c}\text { Govern- } \\
\text { ment }\end{array}$ & Private & Others \\
\hline Low & 10 & 15 & $2(8.30)$ & 19 & 11 \\
& $(41.70)$ & $(62.50)$ & & $(79.20)$ & $(41.80)$ \\
Moder- & $8(33.30)$ & 5 & 4 & 2 & 10 \\
ate & & $(20.80)$ & $(16.70)$ & $(8.30)$ & $(41.70)$ \\
High & $6(25.00)$ & 4 & 18 & 3 & 3 \\
& & $(16.70)$ & $(75.00)$ & $(12.50)$ & $(12.50)$ \\
Total & $24(100)$ & 24 & 24 & 24 & 24 \\
& & $(100)$ & $(100)$ & $(100)$ & $(100)$ \\
\hline
\end{tabular}

Source: Primary survey, 2017; Percentage in brackets

Table 13: Average investment status of respondents

\begin{tabular}{lcc}
\hline Respondents average & \multicolumn{2}{c}{ Frequency } \\
\cline { 2 - 3 } investment period & No. of respondents & $\%$ age \\
Less than 6 months & 10 & 8.30 \\
6 months-1 year & 27 & 22.50 \\
1 year-2 year & 48 & 40.00 \\
More than 2 year & 35 & 29.20 \\
Total & 120 & 100 \\
\hline
\end{tabular}

Source: Primary survey, 2017

\subsection{Average investment status of various respondents}

The average investment period of respondents in accordance to the occupational status of the respective respondents. It was observed that in investment period of less than 6 months $16.7 \%$ respondents of business class make investments while for professionals only $4.1 \%$ investors make investments for less tha 6 months. Out of 24 respondents of government category $4.1 \%$ investors were observed for less than 6 months. For private group $8.3 \%$ respondents make investments short time period and in case of others $20.9 \%$ investors make short time investments. Most of the investors are likely to make there investments for 6 months -1 year. Only government category repondents were observed who were interested to make investments for more than 2 years i.e. 75\% (Table 14).

\subsection{Status of decisions of investors based on various factors}

It was observed that respondent are influenced by various factors regarding their investment. Majority of respondents believe that they get influenced by news as on TV channels better guidance is provided. $75 \%$ of the people think that news is the best way to take the decisions regarding investment as team of financial experts present on media channels can help them in better way. Respondents have also shown that they are not highly dependent on brokers for taking their decisions

\begin{tabular}{|c|c|c|c|c|c|}
\hline \multicolumn{6}{|c|}{ No. of respondents } \\
\hline $\begin{array}{l}\text { Average } \\
\text { invest- } \\
\text { ment } \\
\text { period }\end{array}$ & $\begin{array}{c}\text { Busi- } \\
\text { nessman }\end{array}$ & $\begin{array}{l}\text { Profes- } \\
\text { sional }\end{array}$ & $\begin{array}{c}\text { Govern- } \\
\text { ment }\end{array}$ & Private & Others \\
\hline $\begin{array}{l}\text { Less than } \\
6 \text { months }\end{array}$ & $4(16.70)$ & $\begin{array}{c}1 \\
(4.10)\end{array}$ & $1(4.10)$ & $\begin{array}{c}2 \\
(8.30)\end{array}$ & $\begin{array}{c}5 \\
(20.90)\end{array}$ \\
\hline $\begin{array}{l}6 \\
\text { months-1 } \\
\text { year }\end{array}$ & $9(37.50)$ & $\begin{array}{c}12 \\
(50.00)\end{array}$ & $1(4.10)$ & $\begin{array}{c}5 \\
(20.90)\end{array}$ & $\begin{array}{c}10 \\
(41.70)\end{array}$ \\
\hline $\begin{array}{l}1 \text { year- } 2 \\
\text { year }\end{array}$ & $1(4.10)$ & $\begin{array}{c}6 \\
(25.00)\end{array}$ & $\begin{array}{c}4 \\
(16.70)\end{array}$ & $\begin{array}{c}7 \\
(29.10)\end{array}$ & $\begin{array}{c}2 \\
(8.30)\end{array}$ \\
\hline $\begin{array}{l}\text { More } \\
\text { than } 2 \\
\text { years }\end{array}$ & $\begin{array}{c}10 \\
(41.70)\end{array}$ & $\begin{array}{c}5 \\
(20.90)\end{array}$ & $\begin{array}{c}18 \\
(75.10)\end{array}$ & $\begin{array}{c}10 \\
(41.70)\end{array}$ & $\begin{array}{c}7 \\
(29.10)\end{array}$ \\
\hline Total & $24(100)$ & $\begin{array}{c}24 \\
(100)\end{array}$ & $\begin{array}{c}24 \\
(100)\end{array}$ & $\begin{array}{c}24 \\
(100)\end{array}$ & $\begin{array}{c}24 \\
(100)\end{array}$ \\
\hline
\end{tabular}

Source: Primary survey, 2017; Percentage in brackets

regarding investment due to various scams as seen in day to day life done by brokers that's the reason that only 16 per cent of the respondents have chosen brokers for taking investment decisions. Self-evaluation can be done at the later stage as by people who are involved in trading from a long time. Very less respondents has supported this factor (Table 15).

Table 15: Status of decision of investors based on various factors

\begin{tabular}{lcc}
\hline Factors influencing & \multicolumn{2}{c}{ Frequency } \\
\cline { 2 - 3 } investors decisions & No. of respondents & $\%$ age \\
News & 90 & 75.00 \\
Brokers & 20 & 16.70 \\
Self-evaluation & 10 & 8.30 \\
Total & 120 & 100 \\
\hline
\end{tabular}

Source: Primary survey, 2017

3.16. Demographic respondent's status based on various factors

The investment decision status of various respondents. 83.4 per cent respondents of businessman category have given their responses in favour of news that their decisions regarding investments are influenced by various sources of news (like TV channels, newspapers, radio etc). while professional believe they mostly make there decisions by self evaluation i.e. they choose there portfolios on the basis of there own statics. Government respondesnts have shown their trust in brokers. Private sectors also believe that there investment pattern is so choosen according to the news (Table 16). 


\begin{tabular}{|c|c|c|c|c|c|}
\hline \multicolumn{6}{|c|}{ No. of respondents } \\
\hline $\begin{array}{l}\text { Factors } \\
\text { affecting } \\
\text { invest- } \\
\text { ment } \\
\text { decisions }\end{array}$ & $\begin{array}{c}\text { Busi- } \\
\text { nessman }\end{array}$ & $\begin{array}{l}\text { Profes- } \\
\text { sional }\end{array}$ & $\begin{array}{l}\text { Govern- } \\
\text { ment }\end{array}$ & Private & Others \\
\hline News & $\begin{array}{c}20 \\
(83.40)\end{array}$ & $\begin{array}{c}5 \\
(20.90)\end{array}$ & $2(8.30)$ & $\begin{array}{c}22 \\
(91.80)\end{array}$ & $\begin{array}{c}17 \\
(70.80)\end{array}$ \\
\hline Brokers & $1(4.10)$ & $\begin{array}{c}1 \\
(4.10)\end{array}$ & $\begin{array}{c}20 \\
(83.40)\end{array}$ & $1(4.10)$ & $\begin{array}{c}5 \\
(20.90)\end{array}$ \\
\hline $\begin{array}{l}\text { Self-eval- } \\
\text { uation }\end{array}$ & $3(12.50)$ & $\begin{array}{c}18 \\
(75.00)\end{array}$ & $2(8.30)$ & $1(4.10)$ & $\begin{array}{c}2 \\
(8.30)\end{array}$ \\
\hline Total & $24(100)$ & $\begin{array}{c}24 \\
(100)\end{array}$ & $\begin{array}{c}24 \\
(100)\end{array}$ & $24(100)$ & $\begin{array}{c}24 \\
(100)\end{array}$ \\
\hline
\end{tabular}

Source: Primary survey, 2017; Percentage in brackets

\subsection{Investors' behaviour towards online trading}

While analyzing the beahviour of investors towards the benefits of online stock trading, it was analyzed by Total Weighted Score method and rank analysis. It was observed that wider choices followed by less expenses of the investments was the reason that most of the respondents support online stock trading. Mostly the basic two factors coorelates with the behavour of investors and benefits of online stock trading. Moreover, mean and satandard deviation was also observed, it was noted that largerly investors hold a positive behaviour towards online stock trading. However, standard deviation being 6.3 in the segment of disagree reveals that overall investors believe among the various benefits of online stock trading (Table 17).

\subsection{Investors behaviour towards distrust in online trading}

While analyzing the opinion of respondents towards the reasons for distrusting online trading, it was analyzed by Total Weighted Score method the rank analysis. It was observed that unable to trade (can log in but cant trade), wait and watch attitude and risk of system failure were the key areas in which the respondents were highly concerned ie safety issues. Since these three factors mainly coordinate a linkage between the investors behaviour and resons of distrust for online trading. Moreover, mean and standrad deviation were also observed, it was observed that largely investors had a negative response over the factors mentioned. Howerver standard devaition being 11.4 in the segment of the disagree level reveals that overall respondents were not happy to trade online (Table 18).

Table 17: Investor's behaviour towards online trading

Behaviour of investors towards benefit of online trading (weightage)

Strongly Agree (5) Agree (4) Can't Say (3) Disagree (2) Strongly Agree (1) TWS RANK

\begin{tabular}{|c|c|c|c|c|c|c|c|}
\hline Wider choice & 75 & 20 & 5 & 10 & 10 & 500 & 1 \\
\hline Better value & 40 & 20 & 10 & 12 & 38 & 372 & XII \\
\hline Better return facilities & 35 & 38 & 34 & 8 & 5 & 450 & VI \\
\hline Saves time & 27 & 26 & 40 & 15 & 12 & 401 & IX \\
\hline customer preferences & 43 & 31 & 30 & 14 & 2 & 459 & IV \\
\hline Source of information & 25 & 32 & 28 & 17 & 18 & 389 & XII \\
\hline Inexpensive & 31 & 30 & 20 & 23 & 16 & 482 & ॥ \\
\hline Faster to complete & 27 & 32 & 20 & 23 & 18 & 399 & $X I$ \\
\hline Reduce risk & 35 & 37 & 32 & 8 & 8 & 443 & VII \\
\hline Avoid barriers & 24 & 22 & 30 & 20 & 24 & 362 & XIV \\
\hline Less expensive & 42 & 35 & 29 & 9 & 5 & 460 & III \\
\hline Safety of documents & 35 & 40 & 28 & 5 & 12 & 441 & VIII \\
\hline Access from anywhere & 30 & 25 & 35 & 15 & 15 & 400 & $x$ \\
\hline Cash liquidity & 50 & 20 & 20 & 18 & 12 & 458 & v \\
\hline Convenient & 18 & 32 & 27 & 20 & 23 & 362 & XIV \\
\hline MEAN & 33.875 & 27.75 & 24.4375 & 13.6875 & 13.6875 & & \\
\hline S.D & 15.32264 & 9.13236 & 10.71428 & 6.332127 & 9.421385 & & \\
\hline
\end{tabular}

Source:Primary survey, 2017; Total Weighted Score; $500=75 \times 5+20 \times 4+5 \times 3+10 \times 2+10 \times 1$ 


\begin{tabular}{|c|c|c|c|c|c|c|c|}
\hline \multirow[t]{2}{*}{ Preferences } & \multicolumn{7}{|c|}{ Investors behaviour towards distrust in online trading (weightage) } \\
\hline & $\begin{array}{l}\text { Strongly Agree } \\
\text { (5) }\end{array}$ & Agree (4) & Can't Say (3) & $\begin{array}{c}\text { Disagree } \\
\text { (2) }\end{array}$ & $\begin{array}{c}\text { Strongly Agree } \\
\text { (1) }\end{array}$ & TWS & RANK \\
\hline Inadequate technology & 24 & 32 & 36 & 22 & 6 & 406 & VIII \\
\hline Risk of system failure & 34 & 60 & 12 & 10 & 4 & 470 & III \\
\hline Professional management & 16 & 20 & 44 & 16 & 24 & 348 & XII \\
\hline High transaction cost & 22 & 22 & 44 & 22 & 6 & 380 & XII \\
\hline Lack of sufficient information & 32 & 43 & 5 & 30 & 10 & 417 & VII \\
\hline More chances of fraud & 60 & 20 & 10 & 12 & 18 & 452 & v \\
\hline Poor communication network & 20 & 43 & 22 & 10 & 25 & 383 & $\mathrm{x}$ \\
\hline Lack of transparency & 30 & 6 & 28 & 6 & 50 & 320 & XIV \\
\hline Delay in filling forms & 40 & 42 & 1 & 20 & 17 & 428 & VI \\
\hline Security issues & 60 & 21 & 9 & 17 & 13 & 458 & IV \\
\hline Inadequate infrastructure & 6 & 19 & 5 & 25 & 65 & 236 & $\mathrm{xV}$ \\
\hline Wait and watch attitude & 78 & 10 & 20 & 10 & 2 & 512 & II \\
\hline Risk of new announcements & 10 & 34 & 6 & 50 & 20 & 324 & XIII \\
\hline Unable to trade & 79 & 30 & 1 & 5 & 5 & 533 & 1 \\
\hline Portals runs very slow & 35 & 35 & 5 & 25 & 20 & 400 & IX \\
\hline MEAN & 36.4 & 29.13333 & 16.53333 & 18.66667 & 19.92857 & & \\
\hline SD & 23.00248 & 14.28719 & 15.0564 & 11.46838 & 17.54586 & & \\
\hline
\end{tabular}

Source: Primary survey, 2017; Total Weighted Score; $533=79 \times 5+30 \times 4+1 \times 3+5 \times 2+5 \times 1$

\subsection{Future prospects of online trading}

While analysing the future prospects of online stock trading among different investors, it was analysed by Total Weighted Score method the rank analysis, it observed that the investors believe that in future the online trading will become trustworthy, it will reduce the transaction cost and will provide opportunities at large scale for investment. These factors provide a linkage between the change in technology of trading and adaptability by the investors. Moreover, mean and standard devaition were also observed, it was noted that mostly investors hold a positive response towards the future of online stock trading. However standard deviation being 9.1 in the segment of agree reveals that overall respondents reveals that investors had high level of agreeness towards future of online trading (Table 19).

\begin{tabular}{|c|c|c|c|c|c|c|c|}
\hline \multirow[t]{2}{*}{ Prospects of online trading } & \multicolumn{7}{|c|}{ Future prospects of online trading( weightage) } \\
\hline & $\begin{array}{c}\text { Strongly agree } \\
\text { (5) }\end{array}$ & Agree (4) & $\begin{array}{c}\text { Can't Say } \\
\text { (3) }\end{array}$ & $\begin{array}{c}\text { Disagree } \\
(2) \\
\end{array}$ & $\begin{array}{c}\text { Strongly Agree } \\
\text { (1) }\end{array}$ & TWS & RANK \\
\hline Sock investment information. & 45 & 30 & 15 & 20 & 10 & 440 & $\mathrm{xV}$ \\
\hline More profitable & 32 & 28 & 2 & 38 & 20 & 374 & XVIII \\
\hline Enhance effectiveness in stock trading & 80 & 22 & 1 & 7 & 10 & 515 & VII \\
\hline Provides useful information & 92 & 10 & 0 & 8 & 10 & 526 & III \\
\hline Easy to use & 56 & 32 & 6 & 6 & 20 & 458 & XII \\
\hline Less mental effort & 3 & 5 & 3 & 50 & 59 & 203 & $X X I$ \\
\hline Easy to operate & 75 & 25 & 12 & 4 & 4 & 523 & IV \\
\hline Flexible to interact with & 53 & 40 & 7 & 10 & 10 & 476 & $\mathrm{x}$ \\
\hline Online trading would be a good idea & 34 & 26 & 54 & 6 & 0 & 448 & XIV \\
\hline
\end{tabular}




\begin{tabular}{|c|c|c|c|c|c|c|c|}
\hline \multirow[t]{2}{*}{ Prospects of online trading } & \multicolumn{7}{|c|}{ Future prospects of online trading (weightage) } \\
\hline & $\begin{array}{l}\text { Strongly agree } \\
\text { (5) }\end{array}$ & Agree (4) & $\begin{array}{l}\text { Can't Say } \\
\text { (3) }\end{array}$ & $\begin{array}{l}\text { Disagree } \\
\text { (2) }\end{array}$ & $\begin{array}{l}\text { Strongly Agree } \\
\text { (1) }\end{array}$ & TWS & RANK \\
\hline Wise idea & 10 & 14 & 16 & 30 & 50 & 264 & $\mathrm{XIX}$ \\
\hline $\begin{array}{l}\text { I like the idea of using online trading } \\
\text { for stock trading }\end{array}$ & 80 & 16 & 0 & 14 & 10 & 502 & IX \\
\hline Pleasant experience & 50 & 32 & 8 & 30 & 0 & 462 & $\mathrm{XI}$ \\
\hline Trustworthy & 92 & 20 & 0 & 5 & 3 & 553 & 1 \\
\hline It is not opportunistic & 10 & 10 & 4 & 32 & 64 & 230 & $X X$ \\
\hline It is predictable. & 54 & 26 & 10 & 20 & 10 & 454 & XIII \\
\hline Costs are very low & 93 & 17 & 0 & 0 & 10 & 543 & II \\
\hline Speed is very fast & 82 & 18 & 1 & 9 & 10 & 513 & VIII \\
\hline It is transparent & 28 & 32 & 14 & 22 & 24 & 378 & $\mathrm{XVIII}$ \\
\hline Insecurity for private information & 50 & 20 & 3 & 27 & 20 & 413 & $\mathrm{XVI}$ \\
\hline Unable to get compensation & 80 & 20 & 0 & 18 & 2 & 518 & VI \\
\hline occurrence of fraud and hacker & 92 & 8 & 1 & 8 & 11 & 522 & V \\
\hline Mean & 56.7 & 21.4 & 7.4 & 17.3 & 17 & & \\
\hline SD & 29.2 & 9.1 & 11.9 & 13.1 & 18.3 & & \\
\hline
\end{tabular}

Source: Primary survey, 2017

\section{Conclusion}

Maximum respondents were of the age group 30-40 years who are Doctor, Professor, Advocates, teachers etc.Married respondents were keener to make investments as compared to unmarried. Government officials were largely inclined for investment options involving high risk. As far as investors perception towards future prospects of online stock trading were concern, study has observed that the online trading would emerge as more trustworthy platform of investment, and will provide opportunities at large scale for investment.

\section{References}

Balaji, C., 2014.International Journal of Research in Commerce, IT and Marketing 4(12), 44.

Barber, B., Odean, T., 2002.Online investors: Do the slow die first? Review of Financial Studies 15, 45-88.

Haroun.,2006.International Journal of Electronic Finance1(2), 151-170.

Hou, J., Elliot, K., 2014. Profiling online bidders. Journal of Marketing Theory and Practices18(2), 109-127.

Jain, S., 2013.Online stock trading and e broking in India. International Journal of Finance 1(5),1-8.

Kabra, G., Mishra, K., Dash, K., 2010.Factors influencing investment decision of generation in India: An econometric study.Asian Journal of Management Research 4(1), 113-122.

Maran, K., Sankar, S., 2013. Market trading in India.
International Journal of Marketing and Finance in India 2(3), 1-11.

Pandey, N., Kathavaray, P., 2015. Investment preferences towards commodity market and other investment options, Puddichery, 14.

Pratima, M., Vaddai, K., 2015. Factors influencing online tradingadoption. Asian Research Journal of Business Management 2(3), 39-40.

Rahim, A., 2013.Problems and prospects of online share trading practices in India. International Journal of Marketing Financial Services and Management Research2(4),1-6.

Srivastava, S., 2002. Impact of internet growth on the online stock trading in India. International Journal of Finance and Technology, 240-360.

Syed, T., 2010. An empirical study of Indian individual investors behaviour. Global Journal of Finance and Management 2(1), 19-23.

Vaddai, M., Pratima, M., 2016. Investors behaviour in secondary market. International Journal of Engineering Technology Management and Applied Science 4(1), 113-122.

Walia, N., Kumar, R., 2007.Online stock trading in India. Indian Journal at Marketing 30(8), 150-154.

Xia, L., Sudarshan, D., 2002. Effects of interrupts on consumer online decision process. Journal of Consumer Perception 12(3), 265-280. 